\title{
Program Kemitraan Masyarakat BUDISDAMBER (Budidaya Ikan dan Sayur Dalam Ember) RT 08 RW X Kelurahan Kembangarum Kecamatan Semarang Barat
}

\author{
${ }^{1}$ Slamet Budirahardjo, ${ }^{2}$ Setyoningsih Wibowo*, ${ }^{3}$ Rahmat Robi Waliyansyah \\ ${ }^{1}$ Program Studi Teknik Sipil, Fakultas Teknik dan Informatika, Universitas PGRI Semarang, Indonesia \\ 2,3 Program Studi Informatika, Fakultas Teknik dan Informatika, Universitas PGRI Semarang, Indonesia \\ *Corresponding Author: \\ E-mail: setyoningsihwibowo@upgris.ac.id
}

Received:

1 January 2021
Revised:

15 April 2021
Accepted:

15 May 2021
Published:

31 May 2021

\begin{abstract}
Abstrak
Secara umum warga RT 08 RW X Kelurahan Kembangarum Kecamatan Semarang Barat Kota Semarang berjumlah 40 (empat puluh) Kepala Keluarga. Sebagian besar warga bermata pencaharian sebagai buruh. Dimasa pandemi seperi ini perekonomian warga menjadi sangat memprihatinkan, banyak pabrik-pabrik/industri/tempat bekerja warga mengalami kerugian yang akibatnya beberapa warga kena PHK. Sementara kebutuhan pangan setiap hari untuk keluarga harus terpenuhi. Kegiatan pendampingan warga dimasa pandemic seperti ini sangatlah dibutuhkan dan sangat membantu warga. Pendampingan merupakan salah satu pemberdayaan masyarakat dengan kata lain kegiatan yang mengikutsertakan warga dalam mengembangkan potensi yang ada di lingkungan warga, selain itu bertujuan untuk meningkatkan pengetahuan warga dan meningkatkan kesejahteraan warga. Dalam pendampingan ini kami bertugas sebagai pembimbing, perencana, pemotivasi, sumber informasi, penghubung, fasilitator sekaligus sebagai evaluator. Metode pendampingan ini melalui beberapa tahap, yaitu sosialisasi program, pemaparan materi tentang ketahanan pangan, materi tentang system Budisdamber dan diakhiri dengan evaluasi. Target dari kegiatan ini adalah terciptanya ketahanan pangan secara mandiri, bertambahnya pengetahuan tentang sistem Budisdamber yaitu budidaya ikan dan sayur dalam ember yang dapat dilakukan di lahan yang sempit. Dari hasil post test yang telah diisi oleh bapak/ibu peserta yang mendapatkan amanah untuk memelihara ikan dan sayur, tingkat pemahaman tentang ketahanan pangan sebesar $68.13 \%$ dan tingkat pemahaman tentang system budidaya ikan dan sayur dalam ember sebesar $57.50 \%$. kesimpulan yang diambil bahwa warga sudah dapat mengaplikasikan pengetahuan ini sebagai bekal ketahanan pangan dengan memanfaatkan lahan sempitnya.
\end{abstract}

Kata kunci: Budisdamber; ikan; sayur; ketahanan pangan.

\begin{abstract}
In general, the residents of $R T .08 R W . X$ Kembangarum Village, West Semarang District, Semarang City, totaling 40 (forty) heads of families. Most of the residents work as laborers. During a pandemic like this, the economy of the people is very worrying, many factories / industries / workplaces of residents suffer losses, as a result some residents are laid off. Meanwhile, the daily food needs for the family must be fulfilled. Community assistance activities during a pandemic like this are very much needed and very helpful for residents. Assistance is one of community empowerment in other words, an activity that involves residents in developing the potential that exists in the community, besides that it aims to increase citizen knowledge and improve the welfare of residents. In this assistance, we serve as mentors, planners, motivators, sources of information, liaisons, facilitators as well as
\end{abstract}


evaluators. This mentoring method takes several stages, namely program socialization, presentation of material on food security, material on the Budisdamber system and ending with an evaluation. The target of this activity is the creation of independent food security, increased knowledge of the Budisdamber system, namely the cultivation of fish and vegetables in buckets that can be done in a narrow area. From the results of the post tests that have been filled in by the participating fathers / mothers who received the mandate to raise fish and vegetables, the level of understanding of food security was $68.13 \%$ and the level of understanding of the fish and vegetable cultivation system in buckets was $57.50 \%$. The conclusion was drawn that the residents were able to apply this knowledge as a provision for food security by utilizing their narrow land.

Keywords: Budisdamber; fish; vegetables; food security.

\section{PENDAHULUAN}

\section{Analisis Situasi}

Kelurahan Kembangarum memiliki 10 RW dan 9 RT. Secara umum warga RT 08 RW X Kelurahan Kembangarum Kecamatan Semarang Barat Kota Semarang berjumlah 40 (empatpuluh) Kepala Keluarga. Peta wilayah lokasi diperlihatkan pada Gambar 1. Sebagian besar warga bermata pencaharian sebagai buruh. Dimasa pandemi seperi ini perekonomian warga menjadi sangat memprihatinkan, banyak pabrik-pabrik/industry/tempat bekerja warga mengalami kerugian yang akibatnya beberapa warga kena PHK (Prabawa et al., 2021). Akibat PHK tersebut banyak yang hanya berdiam diri dirumah karena mereka juga bingung mau berbuat apa. Dari sisi sebagai kepala keluarga, banyak warga yang menjadi pekerja serabutan, mereka digaji jika mereka bekerja, jenis pekerjaannyapun beragam, jadi buruh lepas, juru parkir sementara. Dari sisi ibu rumah tangga yang di PHK, mereka lebih memilih berdiam diri dirumah hanya mengandalkan penghasilan dari suami. Permasalahan inilah yang menjadikan perekonomian warga menjadi kocar kacir, yang biasanya mereka tiap bulan mendapatkan penghasilan sekarang mereka tidak berpenghasilan, sementara roda kehidupan harus tetap berputar, terutama dalam pemenuhan kebutuhan pangan sehari-hari. Berdasarkan hal tersebut, kami dari tim berencana untuk membantu memberikan solusi dari dampak PHK tersebut dengan melakukan kegiatan dalam bentuk edukasi dan pendampingan dalam mewujudkan ketahanan pangan keluarga dan kegiatan inipun cukup dilakukan di masing-masing rumah warga.

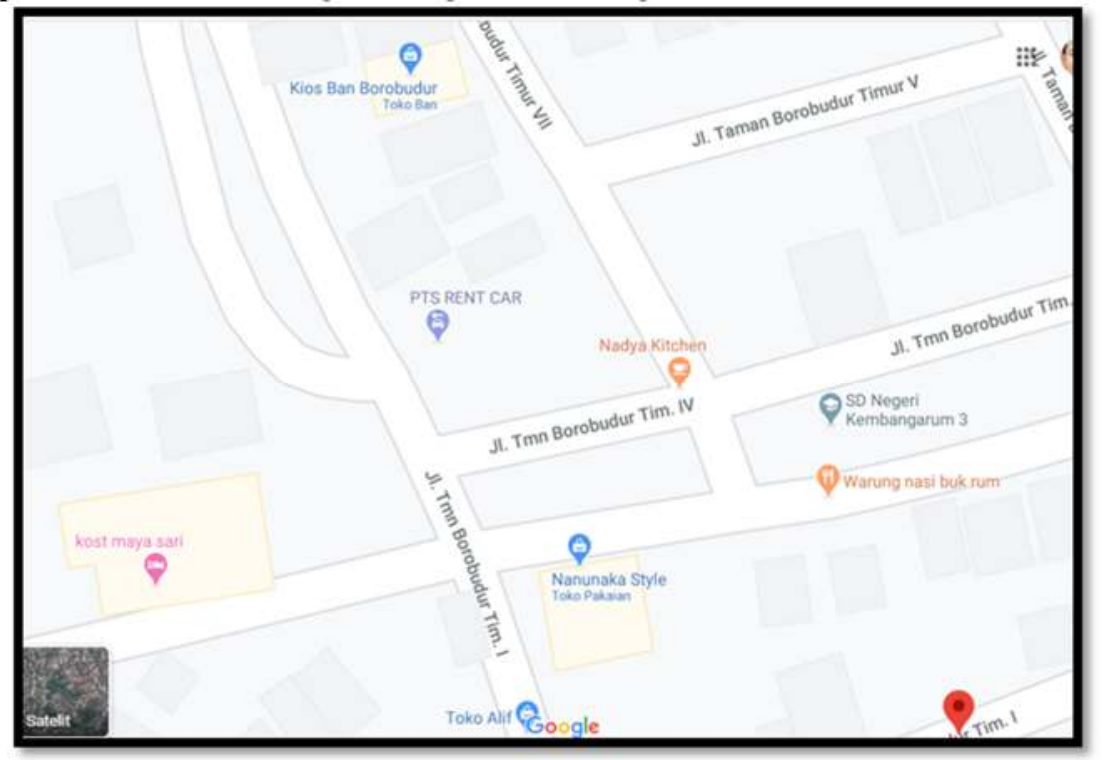

Gambar 1. Peta Wilayah Semarang Barat 
Ketahanan pangan di masa pandemi Covid-19 seperti sekarang ini menjadi sesuatu yang harus diupayakan untuk menghindari krisis pangan yang belum tahu kapan berakhir, kondisi ini sangat terasa dilingkungan masyarakat khususnya bagi warga yang terdampak (Hanifah \& Ningsih, 2020). Himbauan dari pemerintah kepada masyarakat, supaya masyarakat ikut andil dalam menjaga ketahanan pangan untuk menghindari krisis pangan (Febri et al., 2019). Masyarakat diharapkan menjadi lebih kreatip dan bisa berkreasi untuk mengakali situasi yang ada (Masitoh et al., 2020). Termasuk halnya dalam menjaga akses terhadap pangan. Masyarakat diharapkan memiliki kesadaran untuk melakukan penanaman mandiri minimal untuk memenuhi kebutuhan pangan sendiri (Perwitasari et al., 2019). Ada banyak sekali cara untuk melakukan penanaman mandiri seperti misalnya urban farming dan juga melakukan penanaman dengan metode aquaponik dengan memanfaatkan lahan-lahan yang ada di rumah (Hanifah \& Ningsih, 2020). Dalam rangka untuk menjaga ketersediaan pemenuhan kebutuhan pangan keluarga secara mandiri (Setiyaningsih et al., 2020), maka perlu diadakan kegiatan pendampingan di wilayah RT.08 RW.X Kelurahan Kembangarum Kecamatan Semarang Barat Kota Semarang. Gambar 2 memperlihatkan lahan sempit warga yang dapat dimanfaatkan sebagai lahan ketahanan pangan keluarga.
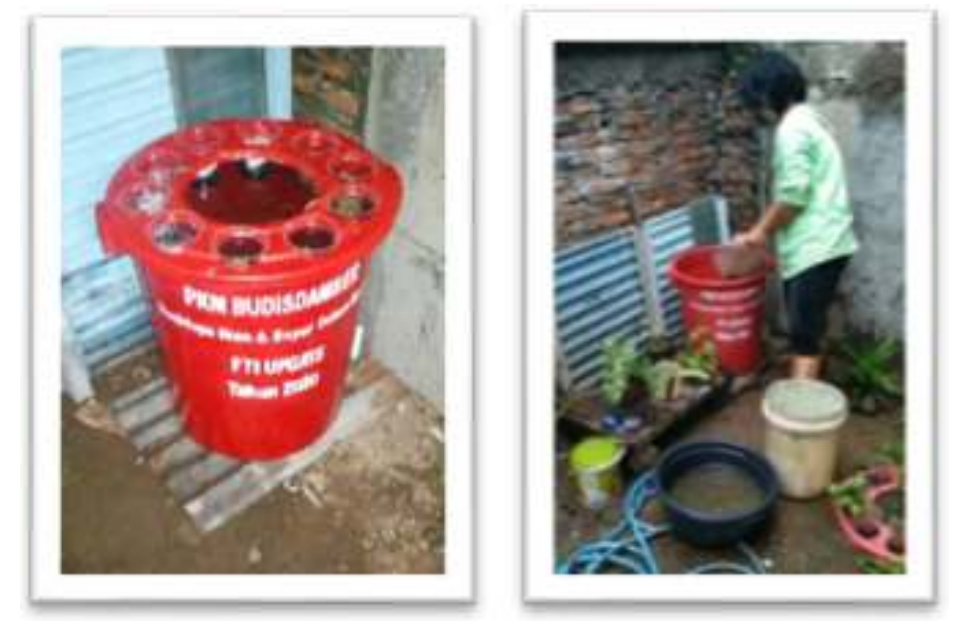

Gambar 2. Lahan Sempit Warga yang Bisa Dimanfaatkan

\section{Permasalahan Mitra}

Efek pandemik Covid-19 ini menyebabkan meningkatnya pengangguran. Berdampak juga pada perekonomian masyarakat, sehingga banyak masyarakat yang mengeluh dan mengalami kehilangan mata pencaharian karena dirumahkan. Warga yang terdampak mengalami penurunan dalam pemenuhan kebutuhan pangan tiap harinya (Mojiono et al., 2020). Dari efek tersebut mengakibatkan warga hanya bisa tinggal diam dirumah dan tak tahu apa yang harus dilakukan (Suryanti et al., 2020).

Oleh sebab itu kami selaku Akademisi dari Fakultas Teknik dan Informatika, Universitas PGRI Semarang melakukan kegiatan Tri Dharma Perguruan Tinggi dengan bentuk program kemitraan masyarakat untuk program "PKM Budisdamber RT.08 RW.X Kelurahan Kembangarum Kecamatan Semarang Barat Kota Semarang" yang bertujuan dapat memberdayakan lahan warga sebagai media pemenuhan kebutuhan pangan yang dapat dilakukan hanya dengan berdiam dirumah (Irfayanti \& Ningsih, 2020). 


\section{METODE}

Metode yang digunakan dalam pelaksanaan ini adalah berupa penyuluhan dan pendampingan. Kegiatan ini diikuti oleh Bapak Ketua RT, Ibu Ketua PKK, Ibu Ketua Dawis dan anggota dawis.

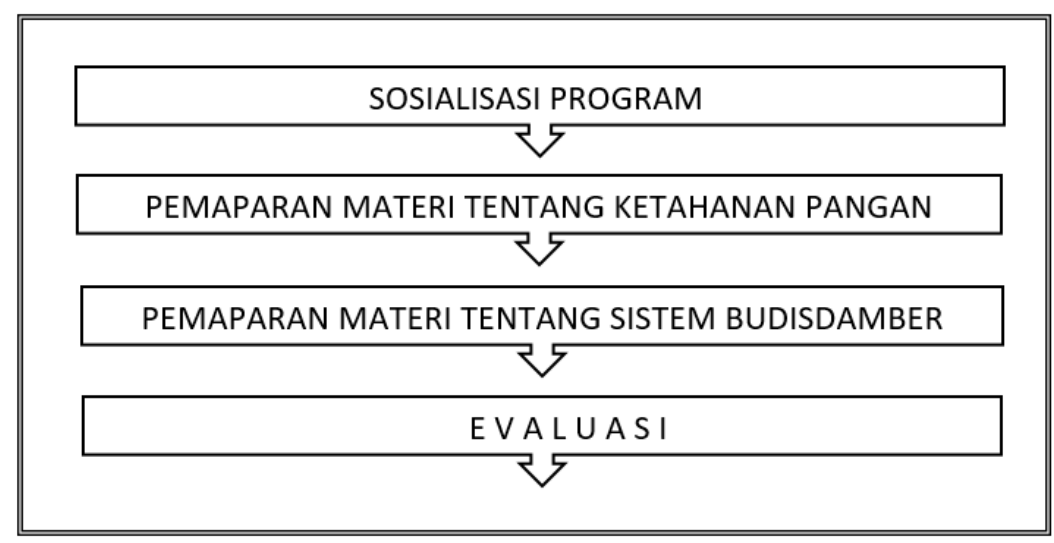

Gambar 3. Tahapan Program Kemitraan Masyarakat

Tahapan yang dilakukan dalam kegiatan ini seperti terlihat pada Gambar 1 di atas, adapun uraiannya adalah sebagai berikut:

Langkah pertama adalah sosialisasi program yang memiliki tujuan untuk memberikan gambaran tentang program yang akan dilaksanakan. Selain itu juga untuk memberikan motivasi dan stimulus ke warga demi terlaksananya program ini. Target peserta adalah bapak-bapak dan ibu-ibu PKK di RT 08 RW X di Kelurahan Kembangarum, Kecamatan Semarang Timur. Gambar 2 memperlihatkan kegiatan sosialisasi program kepada warga. Sosialisasi dilakukan pada saat kegiatan rutin arisan bapak-bapak dan kegiatan PKK.

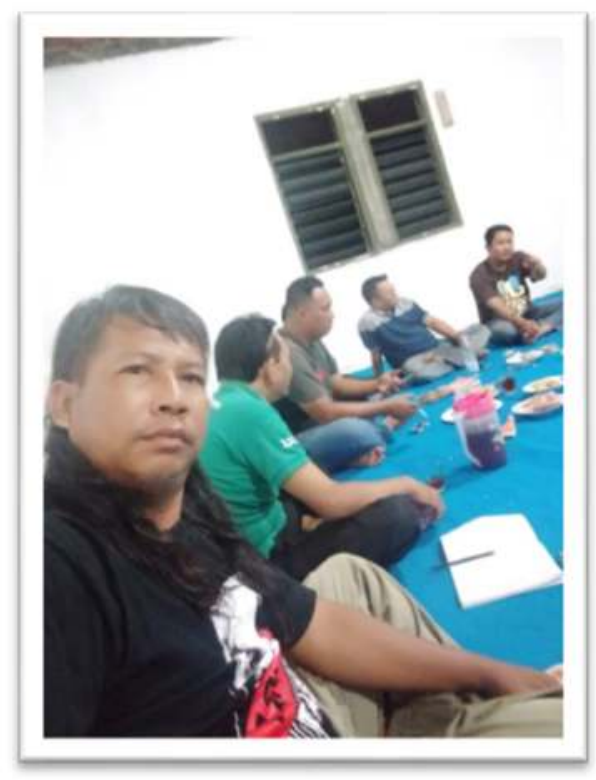

Gambar 4. Sosialisasi Kepada Warga

Langkah kedua adalah pemaparan materi tentang ketahanan pangan dengan cara penyuluhan atau pemberian edukasi kepada warga pentingnya ketahanan pangan di masa pandemi demi terpenuhinya kebutuhan pangan. Menciptakan ketahanan pangan tidak harus dengan lahan 
yang luas dan modal yang besar. Dalam hal ini bisa dilakukan didalam satu wadah yaitu ember, inilah yang menjadi daya tarik warga dalam menciptakan ketahanan pangan. Terlihat pada Gambar 3 tim pengabdian sedang memberikan penyuluhan dan edukasi kepada warga yang hadir tentang ketahanan pangan.

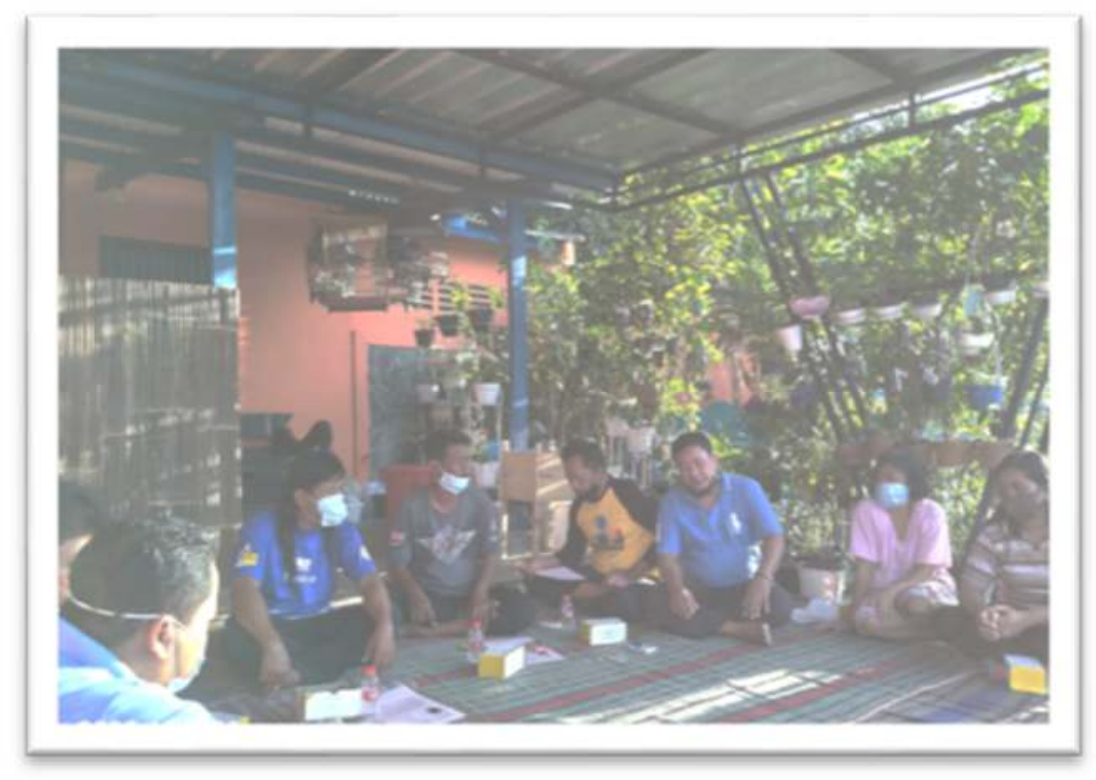

Gambar 5. Sosialisasi tentang ketahanan pangan

Langkah selanjutnya adalah pemaparan materi tentang sistem Budisdamber (budidaya ikan dan sayur dalam ember). Memberikan pengetahuan kepada warga tentang cara sederhana membudidaya ikan dan menanam sayur di dalam ember, dimana kegiatan Budisdamber ini sangat cocok dilakukan di daerah perkotaan yang notabene mempunyai lahan yang tidak terlalu luas/ sempit. Seperti terlihat pada Gambar 4 tim pengabdian memberikan edukasi tentang apa itu budidaya ikan dan sayur dalam ember. Adapun bahan, alat, bibit ikan dan benih tanaman yang dipergunakan pun cukup mudah didapatkan, dan kegiatan Budisdamber dapat dilakukan di masing-masing rumah warga. Dalam kegiatan Budisdamber tersebut, warga diajarkan bagaimana cara mempersiapkan bahan dan alat yang digunakan seperti: ember 80 liter, gelas plastik, arang, pipa pralon, knee pralon, tutup pralon, kawat ram, benih ikan (lele) dan bibit sayur (kangkung), merakit media budidaya ikan (lele) dan media tanam benih kangkung. Pembudidayaan ikan (lele) dan sayur (kangkung) dalam ember meliputi kegiatan perawatan yang dilakukan secara rutin. Perawatan ikan seperti: memberi pakan 2-3 kali sehari, dimana pakan sudah dibibis terlenih dahulu menggunakan cairan probiotik EM4 yang sudah dicampur dengan air, dan mengurangi/ menguras air dalam ember (sipon), jika ikan (lele) terlihat kurang nafsu makan dan menggantung. Budidaya ikan (lele) akan melewati masa penyortiran, adalah kegiatan dimana ikan (lele) akan dipisah sesuai ukuran besar dan kecilnya. Penyortiran ini dapat dilakukan saat ikan berumur satu bulan setelah tebar benih. Perawatan sayur (kangkung) dilakukan jika kondisi daun/ batang sayur terdapat bintik-bintik atau kutu, sebaiknya dibuang. Hasil panen sayur (kangkung) dapat dinikmati setelah 3-4 minggu setelah tebar benih. Dalam sekali tebar benih dapat dipanen berulang kali. Hasil panen ikan dalam hal ini ikan lele dapat dirasakan setelah 2-3 bulan, dengan kisaran panjang ikan (lele) sekitar 30-35 cm (ukuran konsumsi). Jumlah benih ikan (lele) yang dipanen bisa jadi tidak sama dengan jumlah saat ditebar, karena mengalami kematian, yang disebabkan oleh kanibalisme ikan (lele). 


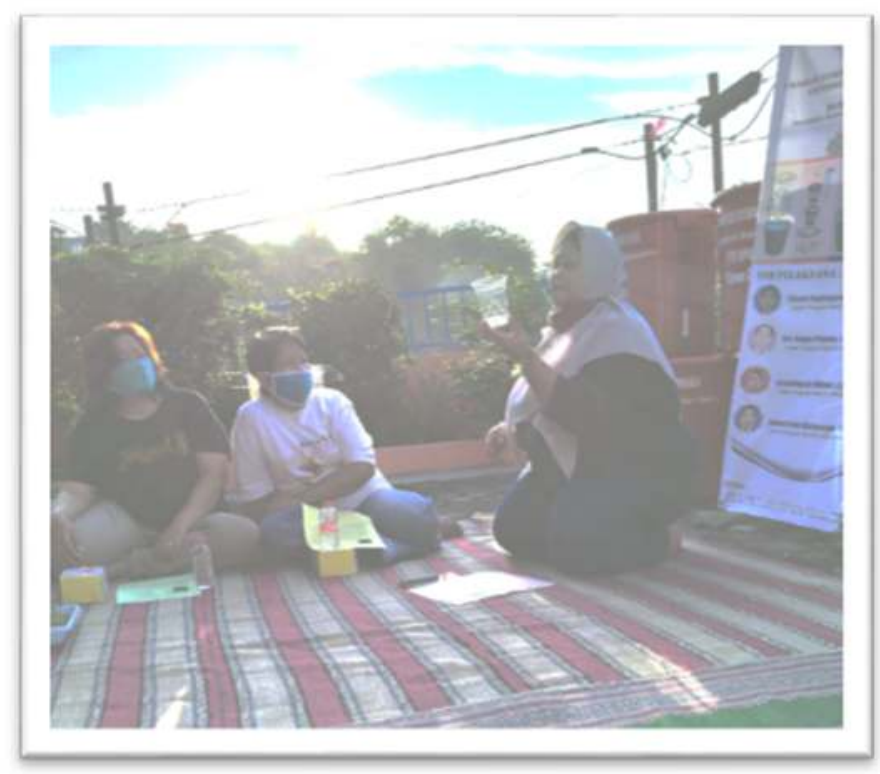

Gambar 6. Sosialisasi tentang Sistem Budisdamber

Langkah terakhir dalam kegiatan ini adalah evaluasi. Evaluasi ini dilakukan untuk memperbaiki setiap kekurangan yang ditemukan selama pengabdian dilaksanakan. Setiap kegiatan dievaluasi dan perbaikan dilakukan berdasarkan hasil evaluasi tersebut. Setelah kegiatan selesai, kemudian diadakan evaluasi dan refleksi hasil kerja penyuluhan. Seberapa besar penguasaan peserta terhadap materi dapat dilihat dari hasil pengetahuan. Keberhasilan kegiatan ini dilihat dari indikator keberhasilan peningkatan pengetahuan, yaitu: (1) Pengetahuan peserta mitra terkait dengan bagaimana usaha dalam menciptakan ketahanan pangan dirumah, dapat dilihat dari nilai tes sebelum dan sesudah ceramah/penyuluhan. (2) Pengetahuan peserta mitra terkait dengan sistem Budisdamber sehingga dapat diimplementasikan dalam aktivitas atau kegiatan sehari-hari.

\section{HASIL DAN PEMBAHASAN}

Adapun hasil dari terlaksananya Program Kemitraan Masyarakat (PKM) sesuai dengan tahapan, (1) Sosialisasi program, dilaksanakan 2 (dua) kali pertemuan, yaitu di Balai RT 08 yang dihadiri oleh Bapak RT, Ibu Ketua PKK dan seluruh warga RT 08. Dalam sosialisasi ini Ketua RT 08 berharap dengan kegiatan ini tercipta ketahanan pangan bagi warganya dan terlebih bagi warga yang terdampak Covid 19. (2) Pemaparan materi tentang ketahanan pangan, yaitu mengedukasi kepada warga pentingnya ketahanan pangan di masa pandemi demi terpenuhinya kebutuhan pangan. Menciptakan ketahanan pangan tidak harus dengan lahan yang luas dan modal yang besar. (3) Pemaparan tentang system Budisdamber, memberikan pengetahuan kepada warga tentang cara sederhana membudidaya ikan dan menanam sayur di dalam ember, hasil panen sayur (kangkung) dapat dinikmati setelah 3-4 minggu setelah tebar benih. Dalam sekali tebar benih kangkung dapat dipanen berulang kali. Hasil panen dari budidaya ikan dalam hal ini ikan lele dapat dirasakan setelah 2-3 bulan dengan kisaran panjang ikan (lele) sekitar 30-35 cm (ukuran konsumsi). Hasil panen dari program ini diperlihatkan pada Gambar 5 di bawah ini.

Dalam pembuatan Budisdamber ini dibutuhkan modal yang tidak terlalu mahal, cukup ember ukuran 80liter, gelas plastik dan kawat, bisa menggunakan bahan-bahan bekas pakai, untuk bibit ikan kita bisa beli langsung ke pemijah ikan lele untuk mendapatkan harga yang lebih murah dari harga di pasar ikan, untuk sayur kangkung didapatkan dari benih kangkung, Budisdamber ini tidak membutuhkan lahan yang besar, hemat waktu dalam pemeliharaan, ikan bisa dipanen, 
kangkung tinggal dipotong. Hasil panen selain dikonsumsi sendiri, dibagi-bagikan ke tetangga sekitar dan dijual jika berlebih. Secara analisis usaha keuntungan ekonomi dari hasil penjualan ikan dan sayur dari budikdamber relatif kecil, lazimnya hasil budikdamber untuk memenuhi kebutuhan pangan keluarga. Jika ingin berpotensi sebagai penghasilan sampingan bisa, tergantung dari jumlah dan volume ember yang dimiliki karena berhubungan dengan kapasitas produksi yang dihasilkan. Secara hasil panen yang berkelanjutan dari hasil produksi ikan dan sayur secara ekonomi menguntungkan jika dibandingkan dengan pembelian langsung dipasar.
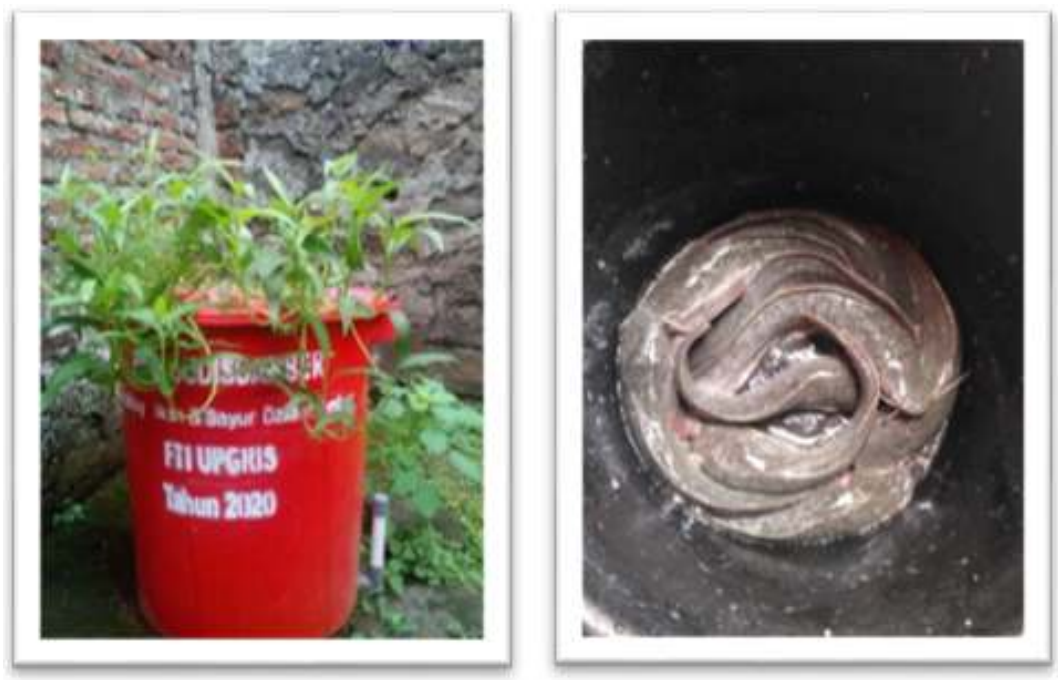

Gambar 7. Hasil Panen

(4) Evaluasi, dari hasil evaluasi secara tertulis, pemahaman tentang ketahanan pangan mengalami peningkatan $68.13 \%$, sedangkan untuk pemahaman sistem Budisdamber $57.50 \%$.

Hambatan yang dialami dalam pelaksanaan pendampingan kegiatan ini adalah daya tangkap para peserta yang berbeda-beda sehingga ada materi yang tidak dapat dicerna dengan baik oleh sebagian peserta dan adanya keterbatasan waktu kegiatan karena sebagian warga bekerja full time jadi hanya bisa dilakukan setelah jam kerja, di hari libur atau malam hari.

\section{KESIMPULAN}

Hasil dari kegiatan ini adalah terciptanya ketahanan pangan secara mandiri, bertambahnya pengetahuan tentang system Budisdamber yaitu budidaya ikan dan sayur dalam ember yang dapat dilakukan dilahan yang sempit. Pendampingan ini mengedukasi warga bagaimana cara memelihara ikan dari tebar bibit ikan, perawatan hingga panen dan mengedukasi warga tentang bagaimana menanam sayur hingga panen. Hasil panen ikan yang dihasilkan lebih terjamin karena pakan full pellet dan airnya terjaga kebersihannya, sehingga menghasilkan ikan yang higienies selain itu juga imunitas warga menjadi bertambah karena ada hiburan dalam memelihara ikan dan sayur.

\section{UCAPAN TERIMA KASIH}

Rasa syukur dan ucapan terima kasih yang tiada terhingga kepada pihak-pihak yang memudahkan terselenggaranya kegiatan pengabdian kepada masyarakat ini: Universitas PGRI Semarang melalui Lembaga Penelitian dan Pengabdian Masyarakat dengan bantuan dana \& programprogramnya yang mempermudah dosen melaksanakan kegiatan, juga kepada rekan-rekan dosen Fakultas Teknik dan Informatika UPGRIS serta warga masyarakat RT. 08 RW. X Kelurahan 
Kembangarum, Kecamatan Semarang Barat yang berkenan mendukung \& membantu diadakannya kegiatan di wilayah tersebut.

\section{DAFTAR PUSTAKA}

Arif, F, A., \& Abdus S. (2020). Study on the Impact of Family-based Food Security Program During The Coronavirus Pandemic. Proceeding The 3rd International Seminar on Family and Consumer Issues in Asia Pacific. 63-68.

Asep, A. H., Lantun, P. D., \& Aulia, A., (2021). Penyuluhan Budidaya Ikan dalam Ember (Budikdamber) di desa Sukapura Kecamatan Dayeuhkolot Kabupaten Bandung. Farmer Journal of Community Services, 47-51.

Dewi, K., Henry, K., Agiska, R, S., \& Juli, N., (2021). Pemberdayaan Kemandirian Kelompok Pengajian BKP Dengan Pelatihan Aquaponic Dalam Pemanfaatan Lahan Sempit Untuk Ketahanan Pangan. Jurnal Pengabdian Nasional Vol 2 (1): 1-10.

Febri, S. P., Alham, F., \& Afriani, A. (2019). Pelatihan BUDIKDAMBER ( Budidaya Ikan Dalam Ember ) di Desa Tanah Terban Kecamatan Karang Baru Kabupaten Aceh Tamiang. Proceeding Seminar Nasional Politeknik Negeri Lhokseumawe, 3(1), 112-117.

Hanifah, E., \& Ningsih, K. (2020). Upaya Peningkatan Ekonomi Masyarakat Dengan Penggunaan Budikdamber ( Budi Daya Ikan Dalam Ember ) Di Tengah Pandemi Covid 19 Di Desa Teja Barat Pamekasan. Seminar Nasional Hasil Pengabdian Kepada Masyarakat (SENIAS) 2020, 65-71.

Irfayanti, D., \& Ningsih, P. W. (2020). Kemandirian pangan dengan pembuatan budikdamber (budidaya ikan dalam ember) di kecamatan telanaipura kota Jambi. Jurnal Pembelajaran Pemberdayaan Masyarakat, 1(4), 350-355.

Juli, N., (2018), Budidaya Ikan Dalam Ember "Budikdamber" dengan Aquaponik di Lahan Sempit. Prosiding Seminar Nasional Pengembangan Teknologi Pertanian. Politeknik Negeri Lampung, 129-136.

Masitoh, N., Sudaryanti, D. S., Munawar, A. H., \& Rahmawati, M. (2020). Optimalisasi Kawasan Rumah Pangan Lestari Dengan Budikdamber Untuk Meningkatkan Ketahanan Pangan Masyarakat Di Masa Pandemic Covid-19 di Desa Sukamahi Kecamatan Sukaratu Kabupaten Tasikmalaya. KOMMAS: Jurnal Pengabdian Kepada Masyarakat, 1(3), 111122.

Mojiono, Qomariah, N., \& Riana, F. (2020). Diseminasi Teknik Budikdamber Lele untuk Produksi Pangan Skala Rumah Tangga Selama Pandemi Covid-19. Jurnal Pengabdian Pada Masyarakat, 5(4), 917-926.

Nursandi, J. (2018). Budidaya Ikan Dalam Ember "Budikdamber" dengan Aquaponik di Lahan Sempit. Prosiding Seminar Nasional Pengembangan Teknologi Pertanian, VII(2013), 129-136. http://jurnal.polinela.ac.id/index.php/PROSIDING

Perwitasari, D. A., Amani, T., \& Tim KKN Desa Gending. (2019). Penerapan Sistem Akuaponik (Budidaya Ikan Dalam Ember) Untuk Pemenuhan Gizi Dalam Mencegah Stunting di Desa Gending Kabupaten Probolinggo. Jurnal Abdi Panca Marga, 1(1), 20-24.

Prabawa, P. S., Suarsana, M., \& Parmila, I. P. (2021). Pelatihan Budikdamber Sebagai Upaya Menjaga Ketahanan Pangan Keluarga Pada Warga Kelurahan Banyuasri, Buleleng. 
BERNAS: Jurnal Pengabdian Kepada Masyarakat, 2(1), 243-249. https://doi.org/10.31949/jb.v2i1.717

Setiyaningsih, D., Bahar, H., Iswan, \& Azis Al-Mas'udi, R. A. (2020). Penerapan Sistem Budikdamber dan Akuaponik Sebagai Strategi dalam Memperkuat Ketahanan Pangan di Tengah Pandemi Covid-19. Seminar Nasional Pengabdian Masyarakat LPPM UMJ (SEMNASKAT), 198-208.

Suaibatul, A., \& Abi, H, D. (2020). Pendampingan Peningkatan Pemberdayaan Masyarakat Desa Betoyoguci, Kabupaten Gresik. DedikasiMU (Journal of Community Service) Vol 2, N0. 3, 472-481.

Suryanti, S., Umami, A., Firmansyah, R., \& Widyasaputra, R. (2020). Pemberdayaan Pertanian Organik dengan Model Hidroganik Budikdamber di Era Pandemi Covid - 19 di Kabupaten Bantul Provinsi DIY. Jurnal Agro Dedikasi Masyarakat, 1(2), 1-6.

Utami, D. P., Sastro, Y., \& Nurjasmi, R. (2015). Peran Media Tanam terhadap Pertumbuhan Serta Hasil Tanaman Kangkung, Sawi, dan Selada dalam Sistem Budidaya Akuaponik. Jurnal Ilmiah Respati Pertanian, 1(6), 462-467.

Yuniar, M., Dian, Y, P., \& Muchamad, U, K, A. (2021). Penyuluhan Daring Manajemen Kualitas Air untuk Budidaya Ikan dalam Ember di Desa Cipacing, Kecamatan Jatinangor, Kabupaten Sumedang, Jawa Barat. Farmers Journal of Community Services, 42-46. 